\title{
The Study of Antioxidant Capacity in Extracts from Vegetal Sources with Hypoglycaemic Action
}

\author{
NELI KINGA OLAH ${ }^{1}$, SORINA PETRESCU ${ }^{2}$, ELEONORA MARIAN ${ }^{3}$, TUNDE JURCA ${ }^{3}$, FELICIA MARC ${ }^{3}$, LUCIANA DOBJANSCHI ${ }^{3}$, \\ ANA HONIGES ${ }^{4}$, RITA KISS ${ }^{5}$, EDWIN SEVER BECHIR ${ }^{6 *}$, FARAH BECHIR ${ }^{6}$, GABRIELA CIAVOI ${ }^{3}$ \\ ${ }^{1}$ Vasile Goldis Western University of Arad, Faculty of Pharmacy, Therapeutic Chemistry, Pharmaceutical Industry and \\ Biotehnologies Department, 86 Liviu Rebreanu Str., 310048, Arad, Romania \\ ${ }^{2}$ SC PlantExtrakt SRL, 407059 Radaia, Cluj-Napoca, Romania \\ 3 University of Oradea, Faculty of Medicine and Pharmacy, 10, 1 Decembrie Sq., 410073 Oradea, Romania \\ ${ }^{4}$ Vasile Goldis Western University of Arad, 94-96 Revolutiei Blvd., 310025, Arad, Romania \\ ${ }^{5}$ University of Debrecen, Pharmacological and Pharmacotherapeutical Institute, 4032, 1 Egyetem ter, Debrecen Hungary \\ 6University of Medicine and Pharmacy of Tirgu Mures, Faculty of Dentistry, 38 Gheorghe Marinescu Str., 540072, Tirgu Mures, \\ Romania
}

\begin{abstract}
In the dental office, diabetes mellitus is a chronic affection that many patients suffer. Apart from the treatment of all diabetic patients, they use homeopathic medicines. We consider the importance of knowing these extracted hypoglycemic plants and their way of acting by the dentist. In this study we investigated some extracts obtained from vegetal sources used by hypoglycaemic action: J uglans regia $L$. -nut, Morus nigra $L$. -black mulberry, Olea europaea L. -olive. We followed the level of antioxidant compounds and the antioxidant capacity in the alcoholic extracts. Our results indicate higher antioxidant efficiency in the extracts from young plant parts, with meristematic tissues, and also a modified phytochemical profile, compared to the extract from mature plant parts.
\end{abstract}

Keywords: Juglans regia L., Morus nigra L., Olea europaea L., phenolic compounds, flavonoids, antioxidant capacity

Type 2 diabetes mellitus consists of an array of dysfunctions characterized by hyperglycemia and resulting from the combination of resistance to insulin action, inadequate insulin secretion, and excessive or inappropriate glucagon secretion, affects a growing number of children [1-3].

There is a special interest for the use of medicinal plants in the treatment of diabetes, in parallel with medical treatment in order to improve the quality of life of the patients.

It was demonstrated that the antidiabetic properties of the plants are attributed mostly to the content of antioxidant compounds [1-6].

The meristemotherapy, or its more used denomination gemmotherapy, was founded as a distinct branch of the phytoptherapy at the begin of the 20th century [7].

Buds and young shoots are parts of plants with meristematic tissues, vegetative parts that are used in gemmotherapy. Gemmotherapy or meristemo-therapy is a field of phytotherapy, which uses buds, young shoots of trees and shrubs. They are harvested in spring, in their natural development cycle, and they are processed fresh, in a mixture of water, alcohol and glycerin.

Buds and young shoots are made up of growing embryonic tissues, containing the entire development power of the future plant, in which the plant's vitality is concentrated. These vegetative organs contain many active compounds that no longer will be present in the mature plant. In addition, because they contain vitamins, oligoelements and minerals, they are richer in nucleic acids and growth hormones than other vegetal tissues [7-18].

\section{Experimental part}

In this study we investigated some extracts obtained from vegetal sources with hypoglycaemic action. We followed the composition of phenolic compounds and total flavonoid contents. Antioxidant capacity of the extracts was evaluated by using DPPH method, FRAP method, CUPRAC assay, SNP method, and by determination of nitric oxide (NO) inhibition.

\section{Plant materials}

There were studied 3 species known for hypoglycemic effect, J uglans regia L. -Nut, Morus nigra L. -black mulberry, Olea europaea L. -olive.

From these species the following vegetative parts were harvested and processed: buds in case of nut and black mulberry; young shoots in case of the olive and leaves in case of nut, black mulberry and olive;

These are processed exclusively in the fresh state, using as extraction solvent a mixture of glycerin -ethanol $96 \%$ vol. (1:1). The extraction ratio is $1: 20$, vegetal material expressed as dry -extraction solvent. Buds and branches have a humidity of around $40-50 \%$. Extraction is carried out by cold maceration (room temperature, max. $30^{\circ} \mathrm{C}$ ), by periodic stirring, $2 \times 10 \mathrm{~min} /$ day for 20 days, followed by decantation, pressing the vegetal material impregnated with solvent, and mixing the extractive solutions (decantation + pressing). The solutions prepared this way, were used for the analysis in this study [7, 19-23].

The nutand black mulberryleaves were processed fresh. The moisture content of the vegetal material is about 65$70 \%$, and the extraction ratio is 1:5 dry vegetal materialextraction solvent. The extraction solvent was ethyl alcohol of $90 \%$ vol.

The olive leaves were processed dry, the extraction ratio is 1:10, vegetal material - ethylic alcohol of $70 \%$ vol. Extraction was carried out in all cases by cold maceration (room temperature, $\max .30^{\circ} \mathrm{C}$ ), by periodical stirring, $2 \mathrm{x}$ $10 \mathrm{~min} /$ day, for 10 days, followed by decantation, pressing of the vegetal material impregnated with solvent, and mixing the extractive solvents (decantation + pressing), and after 5 days of rest, extractive solutions were filtered. These solvents were used for the analyses in this study [ 7 , $19,22,23]$. 
Study of the bioactive compounds of plant extracts

The determination of total flavonoid contents expressed in rutoside

Total flavonoid dosing was performed spectrophotometrically in the visible domain, based on the aluminum ion coordination to the hydroxyl and ketone groups of the flavonoid structure, and the formed complex has a yellow color. Quantitative expression was performed in rutoside, building for this purpose a calibration curve in the rutoside, under similar conditions to the determination performed on the samples. To each $0.1 \mathrm{~mL}$ of the described extracts is added $5 \mathrm{~mL}$ of $10 \%$ sodium acetate and $3 \mathrm{~mL}$ of $2.5 \%$ aluminum chloride. Each solution is brought to 25 $\mathrm{mL}$ with methanol. As standards were used metallogenic solutions of rutoside, having concentrations between 4 and $20 \mu \mathrm{g} / \mathrm{mL}$, processed similarly to the samples. Reading is done at $430 \mathrm{~nm}$, read after 30 min of rest, in triplicate [ 19 , 24-28].

The calibration curve (fig. 1) was obtained with a solution of known concentration of rutoside.

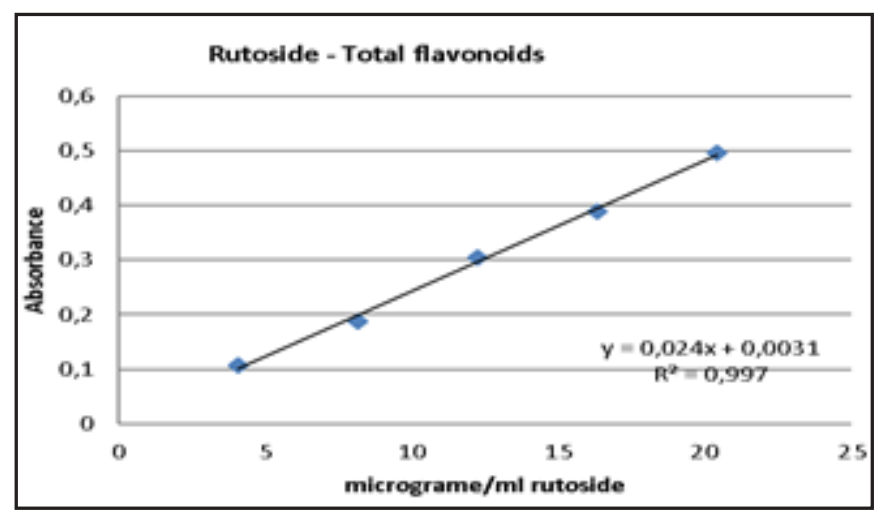

Fig. 1. The calibration curve made with rutoside - total flavonoid contents determination

The determination of total phenolic contents expressed in caffeic acid

Total phenolic acid dozing was performed spectrophotometrically in the visible domain, based on the formation of a blue colored complex between wolfram ions and hydroxyl groups. Quantitative expression was performed in caffeic acid, building for this purpose a calibration curve in the rutoside, under similar conditions to the determination performed on the samples. To each $0.1 \mathrm{~mL}$ of the described extracts is added $0.5 \mathrm{~mL}$ phosphotungstic reagent. Each solution is brought to 25 $\mathrm{ml}$ with sodium carbonate of $15 \%$. As standards were used metallogenic solutions of caffeic acid, having concentrations between 1 and $3 \mu \mathrm{g} / \mathrm{mL}$ ), processed similarly to the samples. Absorbance was measured at $715 \mathrm{~nm}$, read after 2 minutes of rest, in triplicate [19, 24 29]. The calibration curve (fig. 2) was obtained with a solution of known concentration of caffeic acid.

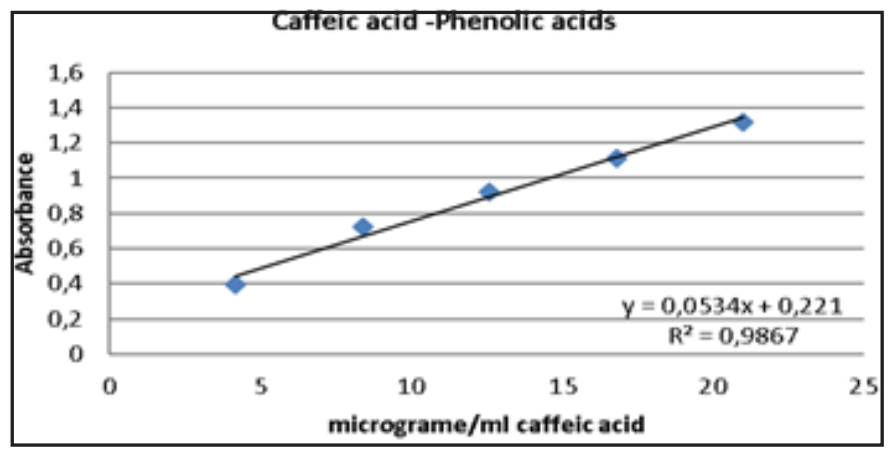

Fig. 2. The calibration curve made with caffeic acid - total phenolic contents determination

\section{Study of the antioxidant capacity}

DPPH method

Radical scavenging activity of plant extracts against stable 2,2-diphenyl-2-picryl-hydrazyl-hydrate (DPPH) was determined by the slightly modified method of BrandWilliams et al 1995 [25]. DPPH reacts with an antioxidant compound, which can donate hydrogen, and reduce DPPH. The change in color (from deep violet to light yellow) was measured at $517 \mathrm{~nm}$ on a UV visible light spectrophotometer. The solution of DPPH in methanol $6 \cdot 10^{-5} \mathrm{M}$ was prepared fresh daily before UV measurements. The samples were kept in the dark for $15 \mathrm{~min}$ at room temperature and the decrease in absorbance was measured. The experiment was carried out in triplicate. Radical scavenging activity was calculated by the following formula:

$$
\% \text { Inhibition }=[(A B-A A) / A B] \times 100
$$

where $A B=$ absorption of blank sample $(t=0 \mathrm{~min}), A A=$ absorption of test extract solution ( $t=15 \mathrm{~min}$ ) [24-29].

\section{FRAP method (ferric reducing antioxidant power)}

FRAP method is a simple spectrophotometric method that assesses the antioxidant power of the studied samples, being based on the reduction of ferric tripyridyltriazine complex [Fe(III)-TPTZ] by a reductant, at an acid $p H$. The stock solutions included: $300 \mathrm{mM}$ acetate buffer; $270 \mathrm{mg}$ $\mathrm{FeCl}_{3} \cdot 6 \mathrm{H}_{2} \mathrm{O}$ dissolved in $50 \mathrm{~mL}$ distillated water; $150 \mathrm{mg}$ TPTŻ and $150 \mu \mathrm{L} \mathrm{HCl}$, dissolved in $50 \mathrm{~mL}$ distillated water. The working FRAP solution was freshly prepared by mixing $50 \mathrm{~mL}$ acetate buffer, $5 \mathrm{~mL} \mathrm{FeCl} \cdot 6 \mathrm{H}_{2} \mathrm{O}$ solution and $5 \mathrm{~mL}$ TPTZ solution. Trolox was used as a standard solution, the calibration curve was made for concentrations between $0-300 \mu \mathrm{M}$, having the correlation coefficient $\mathrm{R}^{2}=0.9956$ and the regression equation $(y=0.0017 x+0.0848)$, where $y$ represents the absorbance detected at $595 \mathrm{~nm}$. The results are expressed as $\mu \mathrm{mol}$ Trolox equivalents (TE) / $100 \mu \mathrm{L}$ extract [30-36].

\section{CUPRAC assay (Cupric ions $\left(\mathrm{Cu}^{2+}\right)$ reducing power)}

In order to determine the cupric ions $\left(\mathrm{Cu}^{2+)}\right.$ reducing antioxidant capacity the method proposed by Karaman et al. (2010) was used with slight modifications [30]. To this end, $0.25 \mathrm{~mL} \mathrm{CuCl}$, solution (0.01 M), $0.25 \mathrm{~mL}$ ethanolic neocuproine solution $\left(7.5 \times 10^{-3} \mathrm{M}\right)$ and $0.25 \mathrm{~mL}$ $\mathrm{CH}_{3} \mathrm{COONH}$ buffer solution (1 M) were added to a test tube, followed by mixing with the plants extracts. Then, total volume was adjusted to $2 \mathrm{~mL}$ with distilled water, and thoroughly mixed. The tubes were stoppered and kept at room temperature. Absorbance was measured at 450 $\mathrm{nm}$ against a reagent blank $30 \mathrm{~min}$ later. Increased absorbance of the reaction mixture indicates increased reduction capability [36-38].

\section{SNP Method (silver nanoparticles)}

Determination of antioxidant capacity by the SNP method was performed spectrophotometrically in the visible domain, based on the reduction of silver ion to colloidal silver, with the formation of fine nanoparticles, the color changing from colorless to yellow or even brown. Quantitative expression was performed in $\mu \mathrm{M}$ trolox equivalent/100 ml extract. The extracts were diluted with purified water, so as to reach the concentrations provided in Table $2.0,8 \mathrm{ml}$ of each sample is mixed with $2 \mathrm{~mL}$ of SNP reagent, obtained from silver nitrate $10 \mathrm{mM}$ and sodium citrate of $1 \%$ at boiling. The solutions are kept for $30 \mathrm{~min}$ at room temperature. As standards were used trolox metallogenic solutions, having concentrations between 20 
and $180 \mu \mathrm{g} / 0,8 \mathrm{~mL}$, processed similarly to the samples. Absorbance was measured at $423 \mathrm{~nm}$, performed in triplicate [39].

Determination of nitric oxide (NO) inhibition

Determination of the NO radical was performed spectrophotometrically in the visible domain, based on the generation of NO radical from sodium nitroprusside at $p H$ 7.4, followed by a diazotization reaction with Griess reagent. Quantitative expression was performed as a percentage of inhibition. Inhibition was calculated with the following formula:

$$
1 \%=\left(A_{\text {ref }}-A_{p}\right) * 100 / A_{\text {ref }}
$$

Extracts were diluted with methanol so that to reach the concentrations provided in table 2. $0.5 \mathrm{~mL}$ of each sample is mixed with $3 \mathrm{~mL}$ of sodium nitroprusside solution in phosphate buffer $0.2 \mathrm{M}$ of $\mathrm{pH} 7.4$. Solutions are kept at $30^{\circ} \mathrm{C}$ for $150 \mathrm{~min}$. After cooling, $0.5 \mathrm{~mL}$ of Griess reagent is added. As standards was used $0.5 \mathrm{~mL}$ ethanol of $70 \%$ or glycerin mixture -ethylic alcohol of $96 \%$ vol. (1:1) processed similarly to the samples. Absorbance was measured at $546 \mathrm{~nm}$, performed in triplicate [40].

\section{Results and discussions}

Figures 3-6 show the inhibition and trolox curves for antioxidant capacity determinations.

In table 1 are presented the equations of the curves mentioned above, and in figures 7, 8, 9, 10, 11, 12, 13 the results of the spectrophotometric determinations.
The nut leave extract has the highest concentration of flavonoids, and the buds of phenolic acids. The maximum antioxidant activity may be found in the extract of nut buds by DPPH, FRAP, SNP methods and inhibits the most powerful NO radicals, while with CUPRAC method, the extract from black mulberry shoots is indicated to have the strongest antioxidant effect (figs. 9, 10, 11, 12, 13).

The results do not show a linear or direct correlation between the antioxidant effect and the content of flavonoids or phenolic acids (figs. 7, 8).

In the series of DPPH determinations may be observed, that Nut and Olive has even a more powerful antioxidant effect than $50.4 \mu \mathrm{g}$ of trolox, antioxidant standard. In this series may be observed correlations between the higher content of polyphenols and the stronger antioxidant effect. But in case of Olive branches it can be concluded clearly that other active compounds besides polyphenols contribute to significant antioxidant activity.

Regardless the used method, the most powerful antioxidant is the extract from nut shoots, which also has a higher concentration of polyphenols, especially flavonoids, which will determine this effect. But the type of these polyphenols also determines a high inhibition of NO radicals, as a result of the effect on the cardiovascular system and endothelium will be decreased in case of the Nut, regardless the part of plan used.

Taking into account the extraction ratio, especially the extracts from buds and branches have a higher antioxidant effect than hydroalcoholic extracts from mature plant parts.

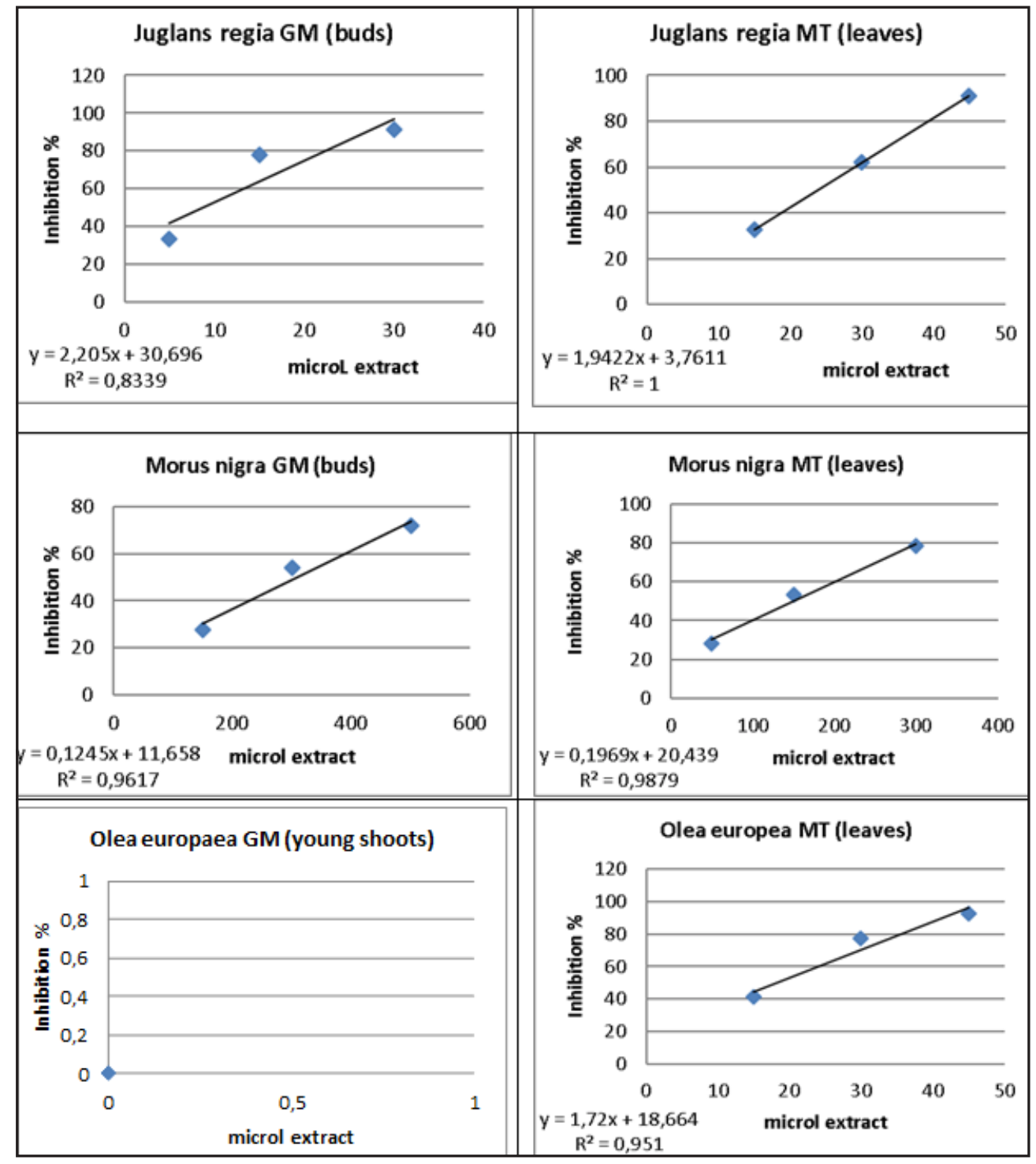

Fig. 3. The inhibition curves by DPPH method 


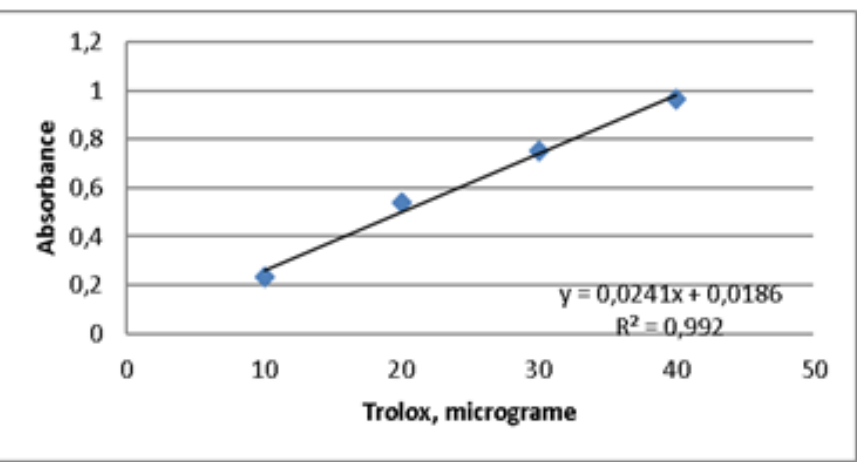

Fig.4. The Trolox curves by the FRAP method - for antioxidant capacity determinations

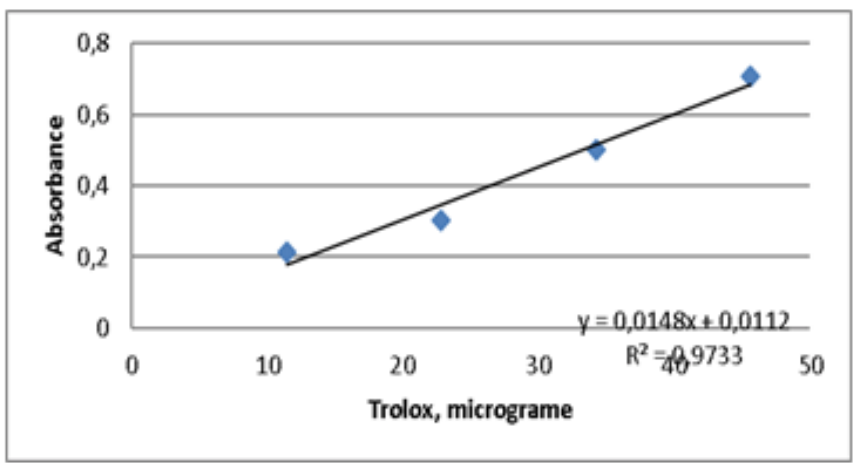

Fig.5. The Trolox curves by the CUPRAC method - for the antioxidant capacity determinations

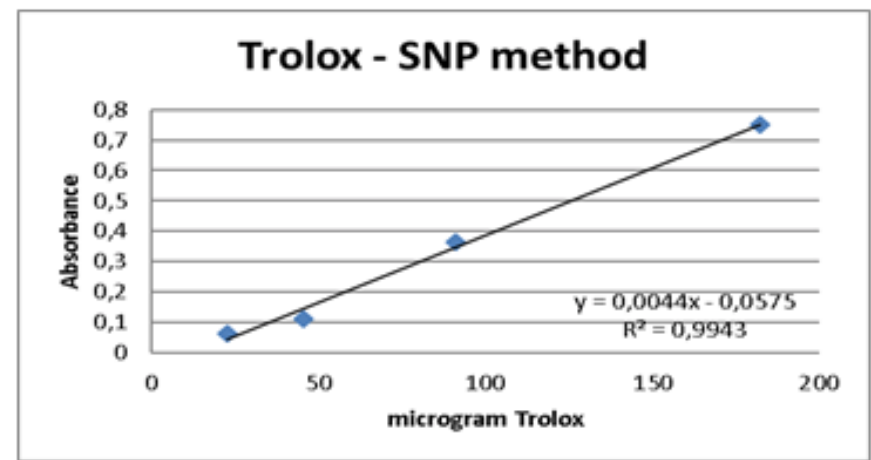

Fig.6. The Trolox curves by the SNP method - for the antioxidant capacity determinations

These indicate the higher therapeutic potential of the gemmotherapy extracts.

The inhibition potential of NO radical is low in case of Black Mulberry and indicates even lower values in case of Olive. This indicates a cardiovascular effect also on vascular endothelium, more significant in case of these species, especially in Olive, this being known for the hypotensive effect.

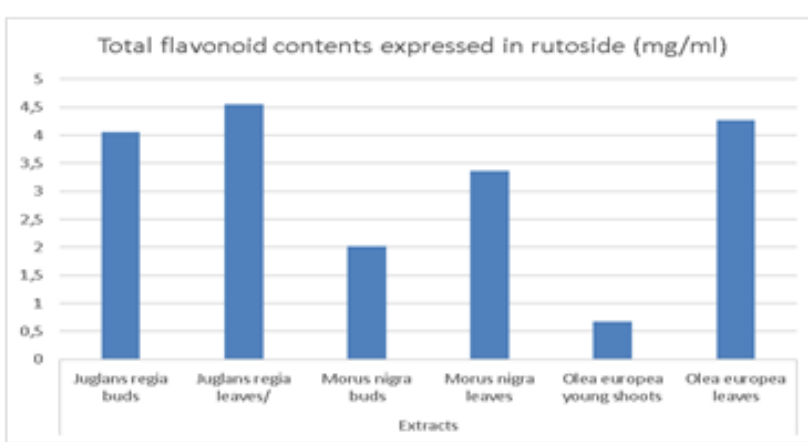

Fig.7. Total flavonoid contents expressed in rutoside $(\mathrm{mg} / \mathrm{mL})$

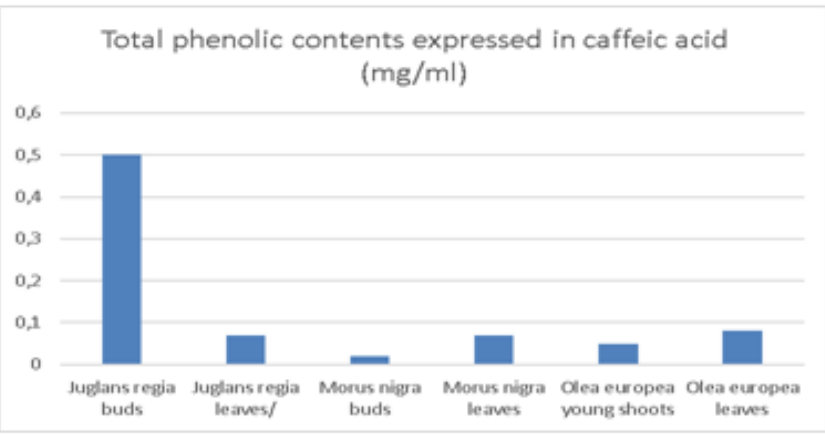

Fig.8. Total phenolic contents expressed in caffeic acid $(\mathrm{mg} / \mathrm{mL})$

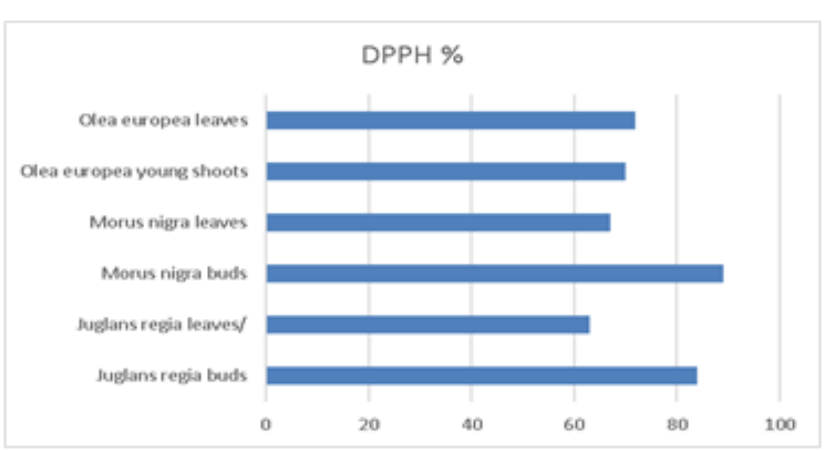

Fig.9. Antioxidant capacity - DPPH (\%)

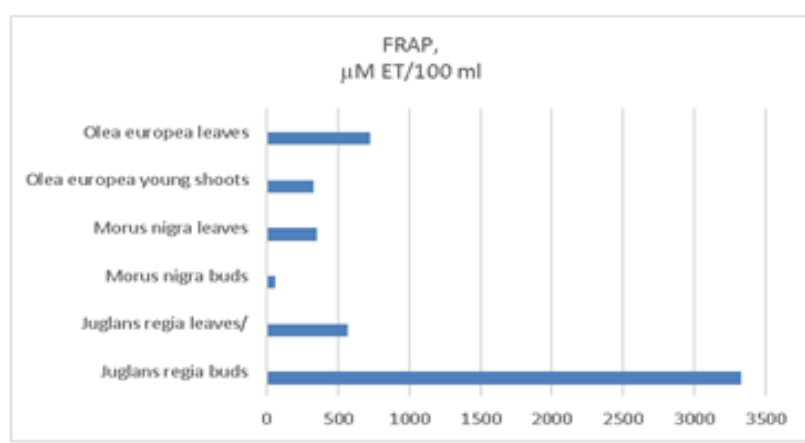

Fig 10. Antioxidant capacity - FRAP ( $\mu \mathrm{M} \mathrm{ET/100} \mathrm{mL)}$

\begin{tabular}{|l|l|l|}
\hline Extracts/Method & Equation & Correlation factor, $\mathbf{R}^{2}$ \\
\hline Juglans regia buds/ (DPPH) & $\mathrm{A}=2,205 \mathrm{xc}+30,696$ & 0,8339 \\
\hline Juglans regia leaves/(DPPH) & $\mathrm{A}=1,9422 \mathrm{xc}+3,7611$ & 1,0000 \\
\hline Morus nigra buds /DPPH) & $\mathrm{A}=0,1245 \mathrm{xc}+11,658$ & 0,9617 \\
\hline Morus nigra leaves /(DPPH) & $\mathrm{A}=0,1969 \mathrm{xc}+20,439$ & 0,9879 \\
\hline Olea europea young shoots/(DPPH) & $\mathrm{A}=1,394 \mathrm{xc}-1,4007$ & 0,9197 \\
\hline Olea europea leaves/(DPPH) & $\mathrm{A}=1,72 \mathrm{xc}+18,644$ & 0,9510 \\
\hline Trolox (DPPH) & $\mathrm{A}=0,8014 \mathrm{xc}+9,6235$ & 0,9972 \\
\hline Trolox (FRAP) & $\mathrm{A}=0,0241 \mathrm{xc}+0,0186$ & 0,9920 \\
\hline Trolox (CUPRAC) & $\mathrm{A}=0,0148 \mathrm{xc}+0,0112$ & 0,9733 \\
\hline Trolox (SNP) & $\mathrm{A}=0,0044 \mathrm{xc}-0,0575$ & 0,9943 \\
\hline
\end{tabular}

Table 1

EQUATIONS OF THE CURVES 


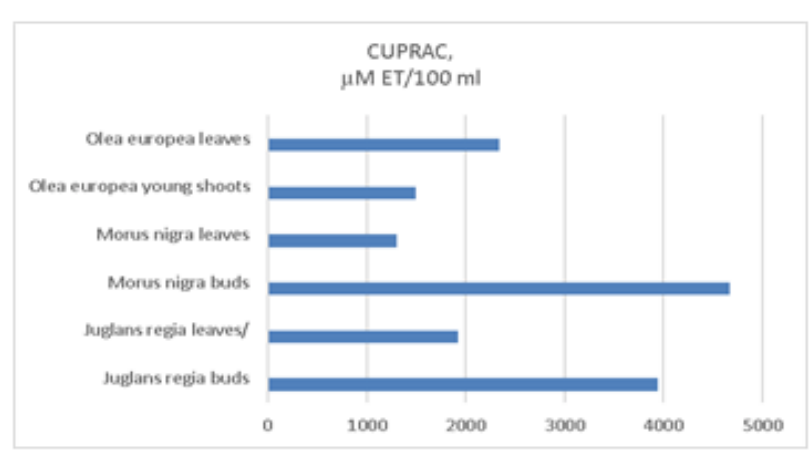

Fig 11. Antioxidant capacity -CUPRAC ( $\mu \mathrm{M} \mathrm{ET/100} \mathrm{mL)}$

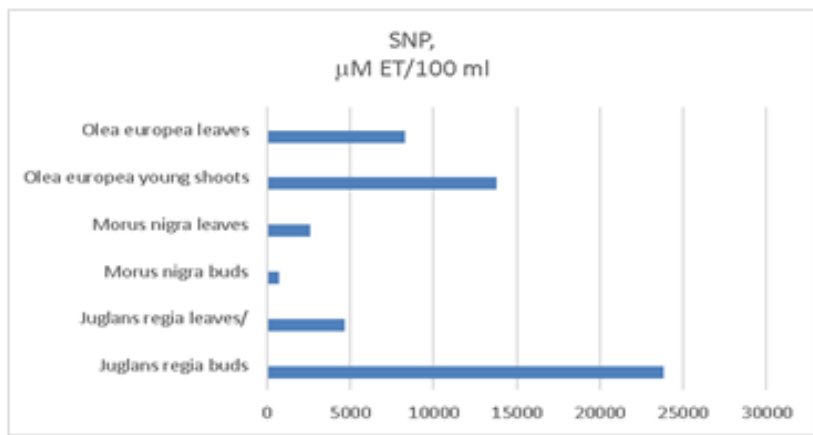

Fig 12. Antioxidant capacity -SNP ( $\mu \mathrm{M} E T / 100 \mathrm{~mL}$ )

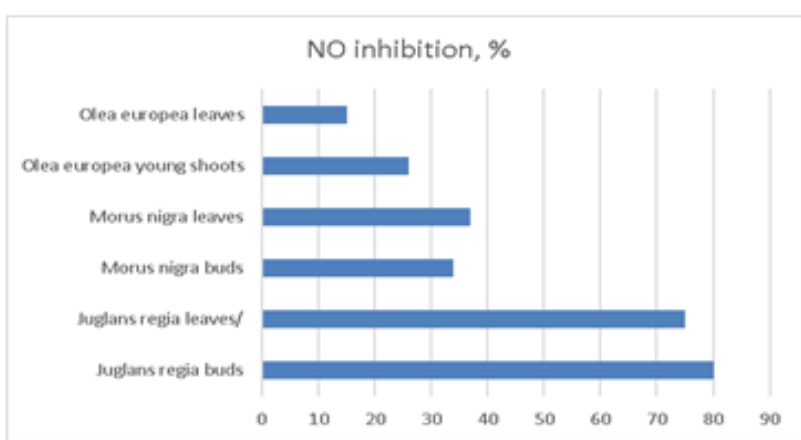

Fig 13. Antioxidant capacity -NO inhibition (\%)

\section{Conclusions}

In this paper we have conducted a study of some extracts from vegetal sources with hypoglycemic action.

The results of this study indicate higher antioxidant efficiency in case of extracts from young plant parts, with meristematic tissues, and also a modified phytochemical profile compared to the extract from mature plant parts.

The results also indicate a potential benefit of Black Mulberry and Olive on cardiovascular system and vascular endothelium, due to the weaker inhibition of NO radicals.

\section{References}

1.BLAIR M., Urol. Nurs., 36, nr.1, 2016, p: 27.

2.KOUPEY D., KOTOLOVA H., KUCEROVA J ., Ceska Slov Farm., 64, nr. $1-2,2015, \mathrm{p}: 3$.

3.DRAGAN, F., LUPU, V.V., PALLAG, A., BARZ, C., FODOR, K., Edited by: Lemle, L.D., INNOVATIVE IDEAS IN SCIENCE 2016, Book Series: IOP Conference Series-Materials Science and Engineering, Volume: 200, 2017, Article Number: UNSP 012063, DOI: 10.1088/1757-899X/200/ $1 / 012063$.

4.PARILDAR H., SERTER R., YESILADA E., J. Pak. Med. Assoc., 61, nr. 11, 2011, p:1116.

5.FAIZA AQ, DUAD A., Diabetes Int, 10, 2000, p:88.

6.MATALA A.A., OMAR M.A.R., PIRIE F.J ., Diabetes Int., 10, 2000, p:44. 7.CHISE E., CAMPEAN RF., COBZAC C., HANGANU D., OLAH NK., TURCUS, V., ARDELEAN A., Studia Universitatis Babes-Bolyai, Chemia, 4, 2016, p: 285.
8.AKAH P.A., OKOLI C.O., NWAFOR S.V., J ournal of Natural Remedies, 2, nr.1, 2002, p: 1.

9.COPOLOVICI, D., BUNGAU, S., BOSCENCU, R, TIT, D. M., COPOLOVICl, L., Rev. Chim.(Bucharest), 68, no. 3, 2017, p. 507.

10.SAMUEL, A.D., BREJ EA, R., DOMUTA, C., BUNGAU, S., CENUSA N., TIT D. M., J. Environ. Prot. Ecol, 18, no. 3, 2017, p. 871..

11.PALLAG, A., JURCA, T, SIRBU, V, HONIGES, A., JURCA, C., Rev.Chim.(Bucharest), 69, no. 2, 2018, p. 445.

12.BUNGAU, S., BUNGAU, C, TIT, D.M., J. Environ. Prot. Ecol., 16, nr.1, 2015, p. 56.

13.SAMUEL, A.D., TIT, D.M., MELINTE (FRUNZULICA), C.E., IOVAN, C., PURZA, L., GITEA, M., BUNGAU, S., Rev. Chim.(Bucharest), 68, no. 10, 2017, p. 2243.

14.BUNGAU, S., SUCIU, R., BUMBU, A., CIOCA, G., TIT, D.M., J. Environ. Prot. Ecol., 16, no. 3, 2015, p. 980

15.PALLAG, A., PASCA, B., JURCA, T., SUCIU, R., NEMETH, S., VICAS, L., Farmacia, 64, nr. 3, 2016, p. 372.

16.PALLAG, A, JURCA, T., PASCA, B., SIRBU, V., HONIGES, A., COSTULEANU, M., Rev. Chim. (Bucharest), 67, no. 8, 2016, p. 1623.

17.MRAZ, CE, MURESAN, M, MICLE, O, VICAS, L, PALLAG, A, COLTAU, M, PUSCAS, I., Farmacia, 60, nr. 2, 2012, p. 264.

18.SIRBU, V, PALLAG, A, HOENIGES, A, COJ OCARU, SI, Rev. Chim., (Bucharest), 68, no. 2, 2017, p. 390.

19.*** European Pharmacopoeia, $9^{\text {th }}$ edition, EDQM, 2017

20.CHIS A.A., GLIGOR F.G., CORMOS G., CUREA E., BOJITA M., Farmacie, 58(5), 2010, p 629-636

21.TASCHINA, M., COPOLOVICI, D.M., BUNGAU S., LUPITU, A.I., COPOLOVICI, L., IOVAN, C., Farmacia, 65, nr. 5, 2017, p. 709.

22.*** German Homeopathic Pharmacopoeia. 2016

23.*** Deutsche Apotheke Verlag, Stuttgart, 2016)

24.COPOLOVICI, L., TIMIS, D., TASCHINA, M., COPOLOVICI, D., CIOCA, G., BUNGAU S., Rev. Chim.(Bucharest), 68, no. 9, 2017, p. 2076.

25.BRAND-WILLIAMS W., CUVELIER ME, BERSET C., Lebenem-Wiss Tehnol., 28, 1995, p.25.

26.J URCA ,T., MARIAN, E., TIA, B., VICAS, S., PALLAG, A., TOTH, I., KRUSPER, L., BRAUN, M., VICAS, L., Rev. Chim.(Bucharest), 68, no. 8, 2017, p. 1786

27.PALLAG, A, ROSCA, E, TIT, DM, MUTIU, G, BUNGAU, SG, POP, OL, Rom J Morphol Embryol, 56, nr. 3, 2015, p. 1103.

28.PALLAG A, FILIP G A, OLTEANU D, CLICHICI S, BALDEA I, JURCA T, MICLE O, VICAS L, MARIAN E, SORITAU O, CENARIU M, MURESAN M, Hindawi, Oxidative Medicine and Cellular Longevity, 2018, ID 3060525 29.MOLYNEUX, P., J. Sci. Technol., 26, nr.2, 2004, p.211.

30.PAPUC, C., CRIVINEANU, M., NICORESCU, V., PREDESCU, C., Rev Chim,(Bucharest), 61, no.7, 2012, p. 619.

31.SINGLETON, V.L., ROSSI, J.A., Am. J. Enol. Viticult., 16, 1965, p.144. 32.KIM, D., CHUN, O., KIM, Y., MOON, H., LEE, C., J. Agric. Food Chem., 51, 2003, p. 6509.

33.GHOLIVAND, M.B., PIRYAEI, M., Afr. J. Biotehnol., 13, nr. 10, 2014, p. 1131.

34.BERTALANIC, L., KOSMERL, T, ULRICH, N.P., CIGIC, B., J. Agric. Food Chem., 60, nr. 50, 2012, p. 11282.

35.WANG, T.C., CHUANG, Y.C., KU, Y.H., Food Chem., 102, 2007, p. 1163.

36.KARAMAN, S., TUTEM, E., BASKAN, K.S., APAK, R., Food Chem., 120, nr. 4, 2010, p. 1201.

37.YUAN, W., ZHOU, L.J ., DENG, G.R., WANG, P., CREECH, D., LI, S.Y., USA. Pharm. C., 2, 2011, p. 11.

38.TALAZ, O., GULCIN, I., GOKSU, S., SARACOGLU, N., Bioorg. Med. Chem., 17, 2009, p. 6583.

39.OZYUREK M., GUNGOR N., BAKI S., GUCLU K., APAK R., Analytical Chemistry, 84, nr.18, 2012, p.8052.

40.ALAM N, BRISTI N.J ., RAFIQUZZAMAN M., Saudi Pharmaceutical J., 21, 2013, p. 143.

$\overline{\text { Manuscript received: } 18.09 .2018}$ 